\title{
Peningkatan Jumlah Mikronukleus pada Mukosa Gingiva Kelinci Setelah Paparan Radiografi Panoramik
}

\author{
Rurie Ratna Shantiningsih*, Suwaldi**, Indwiani Astuti***, dan Munakhir Mudjosemedi* \\ *Fakultas Kedokteran Gigi Universitas Gadjah Mada \\ **Fakultas Farmasi Universitas Gadjah Mada \\ ***Fakultas Kedokteran Universitas Gadjah Mada \\ *J Denta no 1 Sekip Utara, Yogyakarta, e-mail: rr_shantin@yahoo.com
}

\begin{abstract}
ABSTRAK
Mikronukleus merupakan salah satu tanda awal terjadinya kerusakan DNA yang ditemukan pada mukosa gingiva manusia setelah paparan radiografi dental panoramik. Peningkatan jumlah mikronukleus terjadi paling tinggi pada hari ke-10 dan selanjutnya mengalami penurunan sampai dengan hari ke-14. Kelinci memiliki karakter dan periode turn-over mukosa gingiva yang hampir sama dengan manusia berkisar antara 10-12 hari. Tujuan penelitian ini untuk mengevaluasi apakah peningkatan jumlah mikronukleus pada mukosa gingiva kelinci setelah paparan radiografi panoramik.Sembilan ekor kelinci dibagi menjadi 3 kelompok untuk mewakili hari ke-3, 6 dan 9 setelah paparan radiografi panoramik.Sebelum dan sesudah diberikan paparan radiografi panoramik, setiap hewan coba dilakukan apusan pada mukosa gingiva anterior rahang bawah menggunakan cervical brush. Hasil apusan dilakukan pewarnaan dengan modifikasi Feulgen-Rossenbeck dan dihitung jumlah mikronukleus menggunakan mikroskop yang disambungkan dengan optilab. Analisis statistik dilakukan menggunakan paired t-test. Analisis statistik menunjukkan adanya perbedaan yang signifikan $(p<0,05)$ antara jumlah mikronukleus sebelum dan 9 hari sesudah paparan radiografi panoramik. Akan tetapi tidak ditemukan perbedaan yang signifikan ( $p>0,05)$ antara sebelum paparan dibandingkan hari ke-3 dan ke-6 setelah paparan radiografi panoramik. Kesimpulang dari hasil penelitian ini sejalan dengan penelitian sebelumnya pada manusia bahwa peningkatan jumlah mikronukleus terjadi pada hari ke-9 setelah paparan radiografi panoramik. Hasil ini mengindikasikan bahwa pada kelinci juga menunjukkan peningkatan jumlah mikronukleus di mukosa gingiva akibat paparan radiografi panoramik.
\end{abstract}

Maj Ked Gi; Desember 2013; 20(2): $119-125$.

Kata kunci: paparan radiografi panoramik, mukosa gingiva kelinci, micronukleus

\begin{abstract}
Micronucleus Increase After Panoramic Radiography Exposure In Rabbit's Gingival Mucosa. Micronucleus is one of the early states of DNA damage found in human gingival mucosa after dental panoramic radiography exposure. The increasing amount of micronucleus will reach a peak in the tenth day after the exposure, and it will continuously decrease right after the fourteenth day. Rabbit has almost the same gingival mucosa and turn-over period with human for about 10-12 days. The purpose of this research is to evaluate the increasing amount of micronucleus in rabbit's gingival mucosa after panoramic radiography exposure. A total of nine New Zealand rabbits were divided into 3 groups to represent day of $3^{\text {rd }}, 6^{\text {th }}$ and $9^{\text {th }}$ after the panoramic radiography exposure. The mandibular anterior gingival mucosa of each animals was swabbed using a cervical brush before and after panoramic radiography exposure. The samples were stained with Feulgen-Rossenbeck modification, and the amount of micronucleus was counted using a microscope that is connected to Optilab. Statistical analysis was performed using paired $t$-test. The statistical analysis showed that there was significant difference $(p<0.05)$ between the number of micronucleus before exposure and $9^{\text {th }}$ day after panoramic radiography exposure. Moreover, there was no significant difference ( $\left.p>0.05\right)$ between the amount of micronucleus before exposure compared with $3^{\text {rd }}$ and $6^{\text {th }}$ day after panoramic radiography exposure. Based on the experiment, it is concluded that the result is consistent with previous studies conducted in human that there was increasing amount of micronucleus at the $9^{\text {th }}$ day after panoramic radiography exposure. This result indicates that rabbit performs the increasing amount of micronucleus in gingival mucosa because of panoramic radiography exposure.
\end{abstract}

Maj Ked Gi; Desember 2013; 20(2): 119-125.

Keywords: panoramic radiography exposure, rabbit mucosa gingiva, micronucleus 


\section{PENDAHULUAN}

Timbulnya mikronukleus diyakini sebagai marker pada tahap dini mekanisme karsi-nogenesis pada sel yang terkena. ${ }^{1}$ Penelitian Cerqueira ${ }^{2}$, Ribeiro, ${ }^{3}$ maupun Shantiningsih ${ }^{4}$ mendapatkan hasil bahwa radiasi sinar $X$ dari radiografi dental menggunakan teknik panoramik menyebabkan terjadinya efek genotoksik berupa peningkatan jumlah mikronukleus pada sel epitel pada mukosa gingiva dan mukosa bukal manusia. Peningkatan jumlah mikronukleus tersebut maksimal terjadi pada hari ke-10 sesudah paparan dan akan mengalami penurunan pada hari ke-14 setelah paparan dihentikan. ${ }^{2}$ Adanya peningkatan jumlah mikronukleus menunjukkan terjadinya peningkatan frekuensi kerusakan kromosom dan perubahan inti sel akibat paparan radiasi dari radiografi dental teknik panoramik. Hal itu menunjukkan bahwa dosis yang sangat rendah dari paparan radiografi panoramik bukan berarti tidak menimbulkan efek sama sekali terhadap sel dan jaringan hidup yang terpapar. ${ }^{5}$

Hewan coba kelinci sering digunakan secara luas dalam eksperimen karena memiliki kondisi fisiologis yang mirip dengan manusia. ${ }^{6}$ Penggunaan hewan coba sangat bermanfaat untuk mengungkap etiologi, patogenesis, pencegahan dan pengobatan penyakit manusia. Hasil yang diperoleh dari eksperimentasi hewan tergantung pada pemilihan hewan coba yang sesuai. ${ }^{7}$ Hewan coba kelinci memiliki karakter dan periode turn-over mukosa gingiva yang hampir samadengan manusia yaitu berkisar 10-12 hari pada mukosa gingiva. ${ }^{8}$ Hasil eksperimen pada hewan coba diharapkan dapat bermanfaat untuk diekstrapolasi pada manusia. ${ }^{7}$ Tujuan penelitian ini untuk mengevaluasi apakah pada mukosa gingiva kelinci mengalami peningkatan jumlah mikronukleus setelah paparan radiasi radiografi panoramik sehingga dapat digunakan sebagai model hewan coba dalam pembentukan mikronukleus. Dengan adanya hasil penelitian ini diharapkan penelitian selanjutnya mengenai peningkatan mikronukleus akibat paparan radiografi panoramik dapat dilakukan secara in-vivo menggunakan hewan coba kelinci untuk mendapatkan gambaran seperti pada manusia.

\section{METODE PENELITIAN}

Sampel yang digunakan pada penelitian ini berupa hewan coba kelinci galur New Zealand, jenis kelamin jantan, umur 6 bulan, dengan berat sekitar 2-2,5 kg. Pada masing-masing kelinci diberikan paparan radiografi panoramik menggunakan mesin radiografi panoramik merk Yoshida Panoura dengan dosis $80 \mathrm{kVp}, 8 \mathrm{~mA}, 12$ detik untuk satu kali paparan. ${ }^{4}$ Hewan coba kelinci diletakkan dalam kotak kayu berukuran $20 \times 25 \times 20 \mathrm{~cm}$ dengan lubang tempat kepala sebagai tempat fiksasi hewan coba kelinci ketika dilakukan paparan. Ethical Clearance untuk penelitian ini diperoleh dari Komisi Etik Fakultas Kedokteran Gigi UGM. Sembilan ekor kelinci dibagi menjadi 3 kelompok untuk mewakili hari ke-3, 6 dan 9 setelah paparan radiografi panoramik. Pengambilan sampel dilakukan dengan cara melakukan pengusapan pada mukosa gingiva regio anterior rahang bawah bagian bukal pada masing-masing hewan coba, menggunakan cervical brush. Sample yang diperoleh dari mukosa gingiva ditempatkan dalam slide yang bersih dan diberi 2 tetes larutan $\mathrm{NaCl}$ 0,09\%. Selanjutnya pada sampel tersebut dilakukan teknik pembuatan preparat untuk perhitungan jumlah mikronukleus.

Pembuatan preparat dilakukan dengan fiksasi pada sampel yang telah ditempatkan dalam slide dilakukan dengan menggunakan methanol-acetic acid (3:1). Setelah methanol-acetic acid kering, dilanjutkan perendaman dalam $5 \mathrm{M} \mathrm{HCL}$ pada suhu ruang selama 15 menit kemudian slide dicuci dengan akuades selama 10-15 menit. Tahap selanjutnya dilakukan pewarnaan menggunakan metode FeulgenRossenbeck dalam Schiff's reagen selama 90 menit dan dilakukan counterstain dengan fastgreen 1\% selama 1 menit. Pengamatan mikronukleus dilakukan menggunakan mikroskop cahaya perbesaran 40x. Perhitungan dilakukan dengan menjumlahkan sel yang memiliki gambaran adanya inti tambahan berupa mikronukleus. Mikronukleus tersebut berada di sekitar inti utama, memberikan hasil pewarnaan yang sama dengan inti utama dan berukuran lebih kecil, sekitar $1 / 3$ diameter inti utama. 


\section{HASIL PENELITIAN}

Sebelum dilakukan analisis statistik Paired t-test terlebih dahulu dilakukan uji normalitas menggunakan tes Shapiro-Wilk. Jika hasil uji normalitas menunjukkan bahwa data terdistribusi normal, maka analisis statistik dilakukan menggunakan Paired t-test untuk melihat perbedaan jumlah mikronukleus antara sebelum dan sesudah paparan dari radiografi panoramik.

Gambar 1 menunjukkan adanya pening-katan jumlah mikronukleus pada kelompok hari ke-0, 3, 6 dan 9 setelah paparan radiografi panoramik. Peningkatan terbesar nampak pada kelompok hari ke-9 setelah paparan radiografi panoramik. Hasil dari uji normalitas menggunakan uji Shapiro-Wilk ditampilkan dalam Tabel 1.
Uji normalitas dengan tes Shapiro-Wilk pada tabel 1, nampak bahwa data dari jumlah mikronukleus kelompok sebelum maupun sesudah paparan radiografi panoramik pada hari ke-3, 6 maupun 9 memiliki data yang terdistribusi normal. Hal ini dibuktikan dengan nilai signifikansi dari semua parameter menghasilkan P>0,05. Berdasarkan nilai signifikansi $\mathrm{P}>0,05$ tersebut dapat disimpulkan bahwa semua kelompok memiliki sebaran data yang terdistribusi normal. Hasil analisis statistik peningkatan jumlah mikronukleus antara sebelum dan sesudah paparan pada kelompok 3, 6 dan 9 hari akibat paparan radiografi panoramik dirangkum dalam Tabel 2.

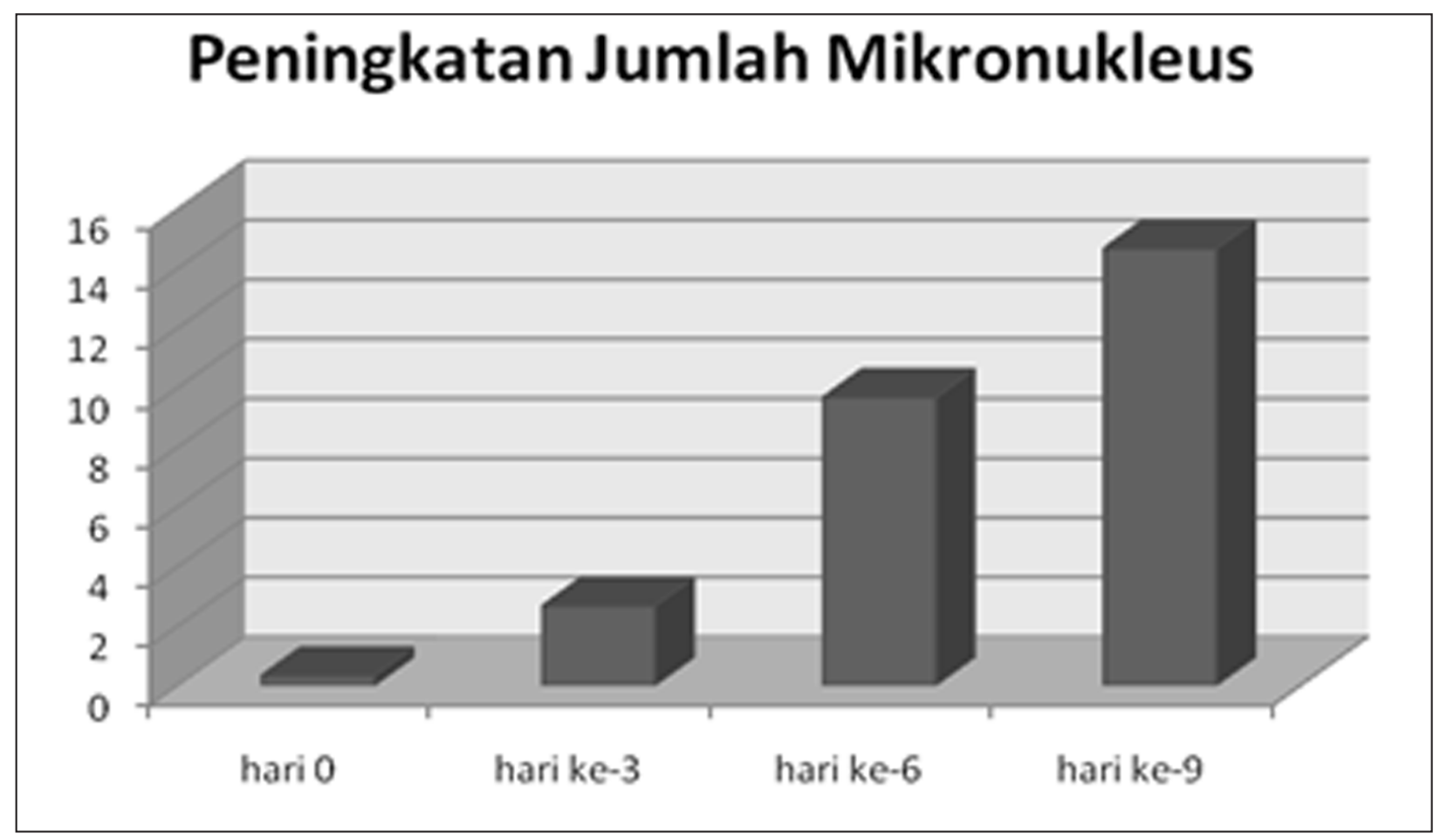

Gambar 1. Rerata peningkatan jumlah Mikronukleus pada mukosa gingiva kelinci hari ke-0, 3,6 dan 9 setelah paparan radiografi panoramik. 
Rurie R.S., dkk.: Peningkatan Jumlah Mikronukleus ...

Tabel 1. Hasil analisis uji normalitas jumlah mikronukleus kelinci pada kelompok hari ke-3, 6 dan 9 sesudah paparan radiografi panoramik

\begin{tabular}{llll}
\hline & \multicolumn{3}{c}{ Shapiro-Wilk } \\
\cline { 2 - 4 } & Statistik & Df & Sig. \\
\hline Mikro sebelum hari 3 & .964 & 3 & .637 \\
Mikro sebelum hari 3 & .871 & 3 & .298 \\
Mikro sebelum hari 6 & .964 & 3 & .637 \\
Mikro sebelum hari 6 & .832 & 3 & .194 \\
Mikro sebelum hari 9 & 1.000 & 3 & 1.000 \\
Mikro sebelum hari 9 & .964 & 3 & .637 \\
\hline
\end{tabular}

Tabel 2. Hasil analisis Paired t-test perbedaan jumlah mikronukleus pada mukosa gingiva kelinci antara sebelum dan 3, 6 serta 9 hari sesudah paparan radiografi panoramik

\begin{tabular}{|c|c|c|c|c|c|c|}
\hline & & \multicolumn{5}{|c|}{ Paired Differences } \\
\hline & & Rerata & $\begin{array}{l}\text { Simpangan } \\
\text { baku }\end{array}$ & $\mathrm{T}$ & Df & $\begin{array}{l}\text { Sig } \\
\text { (2-tailed) }\end{array}$ \\
\hline Pair 1 & $\begin{array}{l}\text { Micro sblm hari } 3 \text { - } \\
\text { Micro sblm hari } 3\end{array}$ & -3.33333 & 2.51661 & -2.294 & 2 & .149 \\
\hline Pair 2 & $\begin{array}{l}\text { Micro sblm hari 6- } \\
\text { Micro sblm hari } 6\end{array}$ & -9.66667 & 5.03322 & -3.327 & 2 & .080 \\
\hline Pair 3 & $\begin{array}{l}\text { Micro sblm hari 9- } \\
\text { Micro sblm hari } 9\end{array}$ & -1.433331 & 4.72582 & -5.253 & 2 & .034 \\
\hline
\end{tabular}

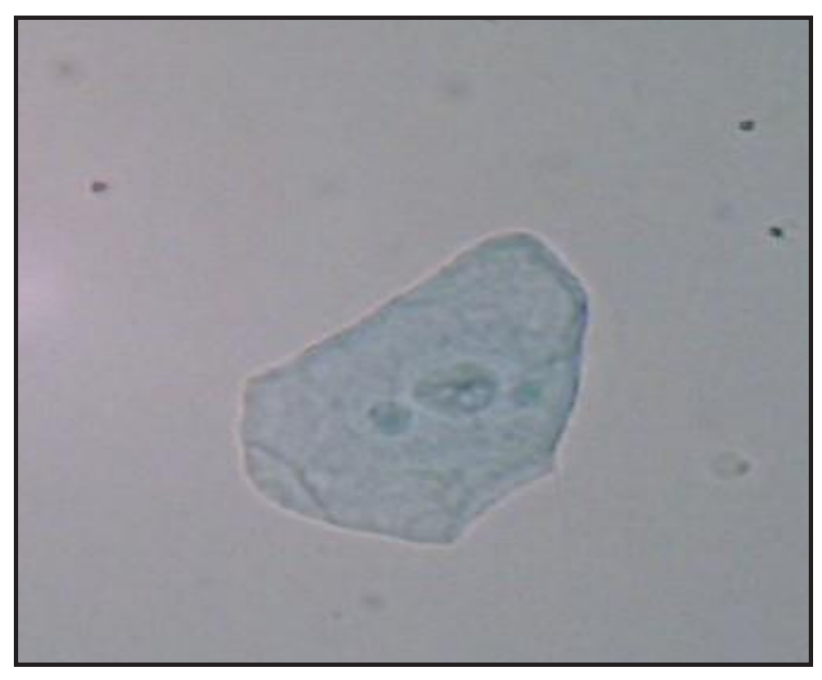

(A)

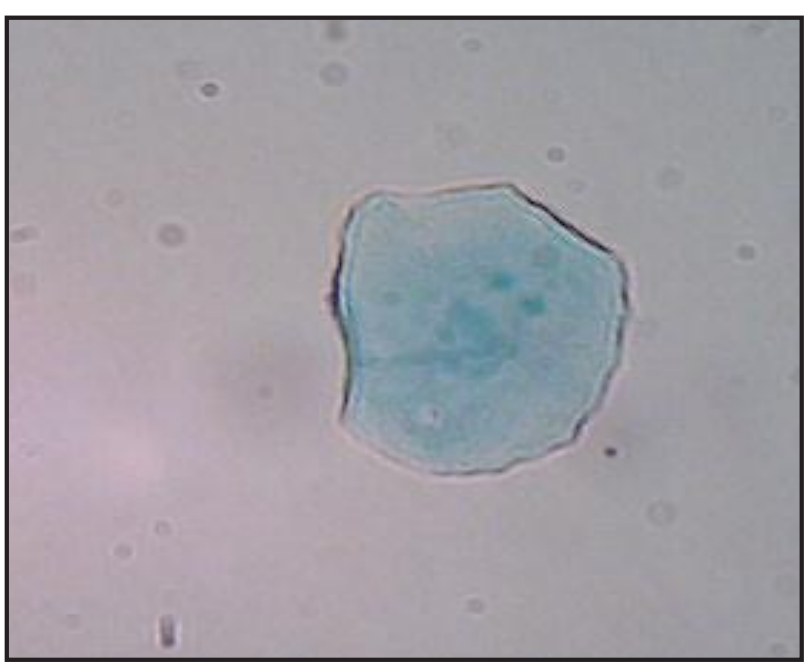

(B)

Gambar 2. Persamaan mikronukleus yang dihasilkan dari mukosa gingiva manusia yang diambil dari hasil penelitian Shantiningsih ${ }^{4}$ dan kelinci. (A) Mikronukleus manusia, (B) Mikronukleus kelinci. 


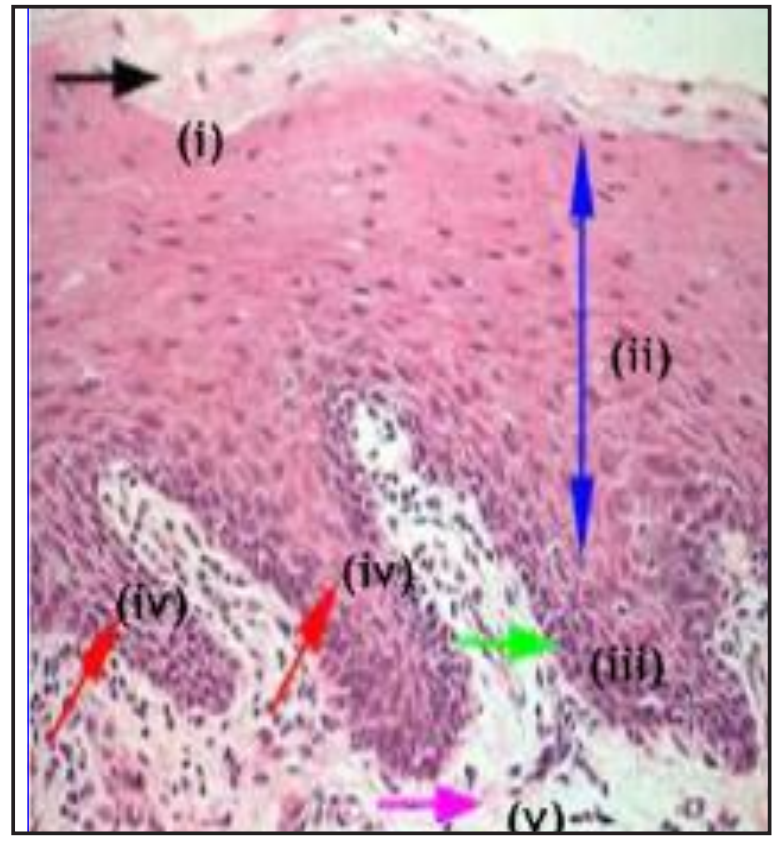

(A)

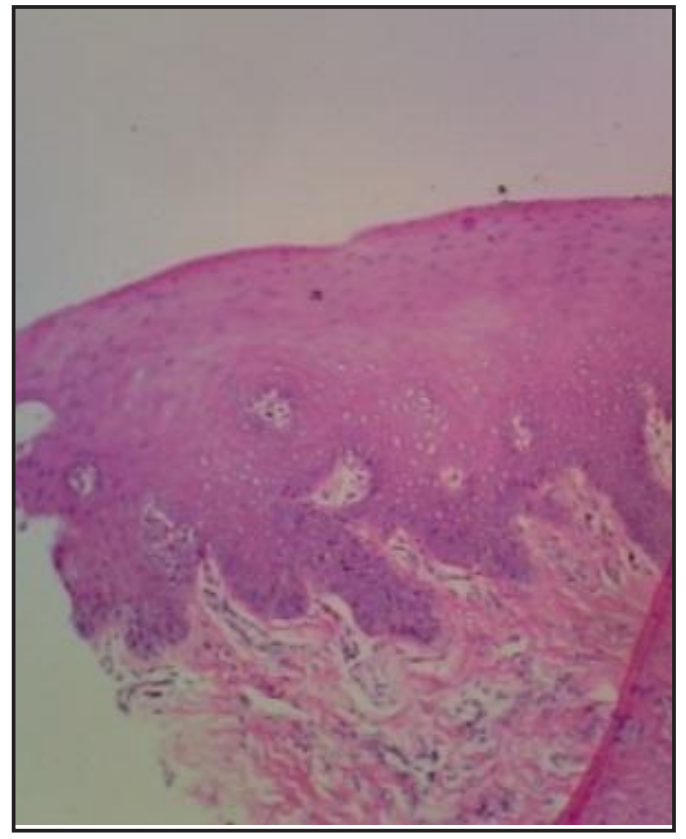

(B)

Gambar 3. Persamaan struktur antara mukosa gingiva manusia dan kelinci. (A) Mukosa gingiva manusia (i) lapisan keratin, (ii) stratum spinosum, (iii) lapisan basal, (iv) retepegs, (v) lamina propria. Gambar (A) diperoleh dari Holland. ${ }^{9}$ (B) Mukosa gingiva kelinci yang diperoleh dalam penelitian ini.

Hasil analisis statistik yang ditampilkan dalam Tabel 2 menunjukkan bahwa perbedaan yang signifikan $(p<0,05)$ jumlah mikronukleus antara sebelum dan sesudah paparan radiografi panoramik hanya nampak pada kelompok hari ke-9. Dilain pihak, pada kelompok hari ke-3 dan 6 menunjukkan hasil perbedaan yang tidak signifikan $(p>0,05)$. Hal ini mengindikasikan bahwa pada kelinci terjadi pula peningkatan jumlah mikronukleus pada 9 hari setelah paparan radiografi pano-ramik. Untuk membandingkan gambar mikronu-kleus yang dihasilkan antara mukosa gingiva manusia dan kelinci ditunjukkan pada Gambar 2.

Gambar 2 menunjukkan bentuk dari mikronukleus pada manusia memiliki persamaan dengan yang dihasilkan pada kelinci. Mikronukleus tersebut berupa bangunan bulat kecil yang terpisah dari inti utama dalam sitoplasma yang terbentuk pada saat pembelahan sel. Ciri dari mikronukleus yaitu berukuran sekitar 1/3-1/5 dari ukuran nukleus utama dan memiliki pewarnaan yang sama dengan nukleus utama. Persamaan struktur histologis antara mukosa gingiva kelinci dan manusia ditunjukkan pada Gambar 3.

Gambar 3 menunjukkan persamaan antara struktur mukosa gingiva manusia dan kelinci. Keduanya memiliki struktur yang berlapis-lapis meliputi lapisan keranitin, stratum spinosum, lapisan basal, rete pegs and lamina propria. Bentuk dari mikronukleus yang dihasilkan oleh manusia dan kelinci juga memiliki kesamaan.

\section{PEMBAHASAN}

Pada penelitian sebelumnya, Cerqueria ${ }^{2}$ dan Shantiningsih ${ }^{4}$ telah menemukan bahwa radiasi sinar $X$ yang dihasilkan akibat teknik radiografi panoramik dapat menyebabkan peningkatan jumlah mikronukleus secara signifikan pada sel epitel dari mukosa gingiva manusia. Jumlah mikronukleus 
tersebut juga akan semakin meningkat pada paparan radiografi panoramik berulang pada mukosa gingiva manusia. Menurut Cerqueira, ${ }^{2}$ antara hari ke-9 dan 10 merupakan waktu yang dianggap paling tepat untuk mendeteksi mikronukleus, terkait dengan periode turnover dari sel epitel. Periode turn over pada gingiva biasa terjadi mulai hari ke-7 sampai dengan hari ke-16. Pada penelitian ini, (Tabel 2) terjadi pula peningkatan yang signifikan jumlah mikronukleus pada mukosa gingiva kelinci pada 9 hari setelah paparan. Hal ini mengindikasikan bahwa pada mukosa gingiva kelinci terjadi pula pembentukan mikronukleus akibat paparan radiografi panoramik seperti yang terjadi pada manusia. Hasil ini konsisten dengan penelitian sebelumnya yang dilakukan pada manusia ${ }^{2,4}$ dan bentuk mikronukleus yang dihasilkan oleh manusia juga sama dengan yang dihasilkan oleh kelinci (Gambar 2).

Mukosa oral hewan seperti monyet, anjing, babi dan kelinci memiliki fungsi dan gambaran fisiologis yang sangat mirip dengan mukosa oral manusia. Pada kelinci, mukosa gingiva dan bukal tidak memiliki batas antara tipe yang terkeratinisasi dan nonkeratinisasi. Pada hewan coba kelinci ditemukan pula memiliki periode turn-over miripdengan manusia danbervariasi berdasarkan karakter dan lokasi mukosa mulut. Pada mukosa bukal berkisar antara 5-6 hari dan mukosa gingiva berkisar antara 10-12 hari. ${ }^{8}$ Penelitian menggunakan hewan coba kelinci juga sering dilakukan dalam penelitian yang berhubungan dengan jaringan periodontal termasuk diantaranya mukosa gingiva. Hewan coba kelinci memiliki gambaran biologis dan struktur jaringan periodontal yang mirip dengan manusia sehingga sering digunakan dalam penelitian terutama yang berkaitan dengan regenerasi jaringan periodontal. ${ }^{9}$ Pernyataan ini dibuktikan dalam Gambar 3, yang menunjukkan persamaan struktur mukosa gingiva antara manusia dan kelinci.

Mukosa gingiva merupakan tempat yang paling banyak terpapar sinar $\mathrm{X}$ dari radiografi panoramik. ${ }^{2}$ Mikronukleus berasal dari patahan kromosom yang gagal mencapai sentromer pada saat periode anafase terjadi pembelahan sel. Indeks mikronukleus pada rodensia dan atau manusia dapat dijadikan salah satu sitogenetik standar dan biomarker yang digunakan dalam toksikologi genetik secara in-vivo dan in-vitro. ${ }^{10}$

\section{KESIMPULAN}

Terdapat peningkatan jumlah mikronukleus dari mukosa gingiva kelinci pada hari ke-9 setelah paparan radiografi panoramik. Dengan demikian dapat disimpulkan bahwa kelinci dapat digunakan sebagai model hewan dalam pembentukan mikronukleus sebagai akibat dari paparan radiografi panoramik.

\section{DAFTAR PUSTAKA}

1. Pawitan JA. The Micronucleus test: a method used in mutagenicity testing. Med.J.Indones. 1995; 4(2):6571

2. Cerqueira EMM, Meireles JRC, Lopes MA, Junqueira VC, Gomes-Filho IS, Trindade S, Machado-Santelli GM. Genotoxic effects of X-rays on keratinized mucosa cells during panoramic dental radiography. DMFR. 2008; 37: 398-403

3. Ribeiro DA, de Oliveira $G$, de Castro GM, Angelieri F. Cytogenetic biomonitoring in patients exposed to dental X-rays: comparison between adults and children. DMFR. 2008; 37: 404-7

4. Shantiningsih RR. The number of micronucleus between single and repeated $\mathrm{x}$-rays exposure of panoramic radiography patients. Proceeding Book: The $2^{\text {nd }}$ International Joint Symposium on Oral and Dental Sciences di Yogyakarta. 2012; 129-33

5. Wall BF, Kendall GM, Edwards AA, Bouffler $S$, Muirhead CR, Meara JR. What are the risks from medical $X$-rays and other low dose radiation? Br.J.Radiol. 2006; 79: 285-94

6. Kusumawati D. Bersahabat dengan hewan coba. Yogyakarta: Gadjah Mada University Press; 2004. H. 12-4

7. Mangkoewidjojo S. Hewan, Eksperimentasi hewan, profesi dokter hewan peranan dan masalahnya di bidang biomedik. Yogyakarta. Pidato Purna Bhakti Universitas Gadjah Mada. 2003; 4-9 
8. Misra A. Challenges in delivery of therapeutic genomics and proteomics. Elsivier Inc. 2011; 482-3

9. Dannan A, Alkattan F. Animal Models in Periodontal Research: A Mini-Review of the Literature, The Internet J. Veterinar Med. 5(1). 2008. http:// www.ispub.com/journal/the-internet-journal-ofveterinary-medicine. diunduh pada 19-1-2012
10. Holland $\mathrm{N}$, Bolognesi C, Kirsch-Volders $M$, Bonnasi S, Zeiger E, Knasmueller S, Fenech $M$. The Micronucleus assay in human buccal cells as a tool for biomonitoring DNA damage: The HUMN project perspective on current status and knowledge gaps. Mutat Res. 2008; 659: 93-108 